Огляди літератури, оригінальні дослідження, погляд на проблему

УДК 616.37-002.2:616.13-004.6]-036-056

DOI 10.11603/1811-2471.2017.v0.i4.8357

\title{
СТРАТИФІКАЦІЯ МОДИФІКУЮЧИХ ФАКТОРІВ РИЗИКУ АТЕРОСКЛЕРОЗУ У ХВОРИХ НА ХРОНІЧНИЙ ПАНКРЕАТИТ
}

\author{
๑є. С. Сірчак, С. М. Опаленик \\ ДВНЗ «Ужгородський національний університет»
}

PЕзЮМЕ. В статті описано та проаналізовано вплив основних модифікуючих факторів ризику атеросклерозу у хворих на хронічний панкреатит.

Мета дослідження - виявити та дослідити наявність факторів ризику атеросклерозу у хворих на хронічний панкреатит в поєднанні з дисліпідемією.

Матеріал і методи. Всім хворим було проведено ${ }^{13} \mathrm{C}$-змішаний тригліцеридний дихальний тест $\left({ }^{13} \mathrm{C}-3 \mathrm{~T} Д\right)$ та ${ }^{13} \mathrm{C}$-амілазний дихальний тест $\left({ }^{13} \mathrm{C}-\mathrm{AДТ}\right)$ для виявлення зовнішньосекреторної недостатності підшлункової залози (ЗСН П3). Атеросклеротичні зміни діагностували вимірюючи товщину шару «інтиму-медіа» у сонній артерії та за наявністю порушень в ліпідограмі (визначенням вмісту загального холестерину плазми крові (3X), тригліцеридів (ТГ), холестерину ліпопротеїдів високої щільності (ЛПВщ) і ліпопротеїдів низької щільності (ЛПнщ), коефіцієнта атерогенності (КА)).

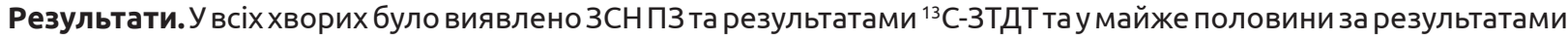
${ }^{13}$ С-АДТ. У всіх пацієнтів було виявлено порушення ліпідного спектра крові у вигляді гіперхолестеринемії, гіпертригліцеридемії, підвищення коефіцієнта атерогенності. Доведено, що ожиріння чи недостатня маса тіла не може слугувати критерієм визначення ступеня ЗСН ПЗ чи тяжкості атеросклеротичних порушень у хворих на ХП в

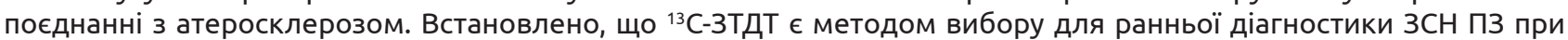
ураженніпЗ.За допомогою методів тестування, анкетуваннята опитування виявлено вагомий впливмодифікуючих факторів ризику атеросклерозу на перебіг ХП.

КлючовІ СловА: атеросклероз; хронічний панкреатит; модифікуючі фактори ризику.

Вступ. Атеросклероз $є$ однією з основних проблем охорони здоров'я всіх високорозвинених країн світу та характеризується постійною тенденцією до зростання. Поряд з атеросклерозом росте і поширеність патогенетично зв' язаних із ним захворювань. Згідно з статистичними даними, у світі до 2020 року смертність від атеросклерозу та його ускладнень може сягнути $60 \%[2,4]$. Атеросклероз - це системне дегенеративне захворювання, яке характеризується ураженням всіх артеріальних басейнів організму. Саме атеросклероз $\epsilon$ однією з найчастіших причин порушення прохідності вісцеральних гілок черевного відділу аорти та супроводжується хронічним порушенням вісцерального кровообігу. Це, в свою чергу, супроводжується ішемією органів черевної порожнини, в тому числі і підшлункової залози (ПЗ) $[3,4]$.

Тяжкість діагностики та труднощі в лікуванні створюють коморбідні патології, які ускладнюють одна одну, а також значною мірою погіршують якість життя таких пацієнтів. Згідно з результатами багатьох клінічних досліджень $[1,2,4,5]$, такі модифікуючі фактори ризику як дисліпідемія, куріння, артеріальна гіпертензія, надлишкова маса тіла, гіподинамія, постійні стреси, надмірне вживання алкоголю $є$ тригерними не тільки для розвитку атеросклерозу, а й для розвитку гострого чи загострення хронічного панкреатиту.

Саме тому для запобігання ускладненням, а також для покращення якості життя Хворих на ХП в поєднанні з атеросклерозом важливими $є$ раціональна оцінка та виявлення найбвагоміших модифікуючих факторів ризику атеросклерозу для своєчасної їх корекції.

Мета роботи-визначити основні модифікуючі фактори ризику у хворих на атеросклероз та дослідити їх вплив на перебіг хронічного панкреатиту у даних пацієнтів.

Матеріал і методи дослідження. Дослідження проведено в групі 44 хворих на ХП та атеросклероз. Вік хворих становив від 32 до 64 років (середній - $(47,12 \pm 2,01)$ р.). Серед обстежених було 17 (39\%) жінок та 27 (61 \%) чоловіків. Усі хворі перебували на стаціонарному лікуванні у гастроентерологічному та ендокринологічному відділеннях ЗОКЛ імені А. Новака в м. Ужгород чи на амбулаторно-диспансерному спостереженні у сімейного лікаря та гастроентеролога за місцем проживання. Контрольну групу склали 20 практично здорових осіб (ПЗО) віком від 34 до 67 років (середній - $(44,21 \pm 3,1)$ р.). Серед обстежених контрольної групи жінок було 7 (35\%), чоловіків - 13 (65\%).

Діагноз ХП встановлювали згідно з марсельсько-римськими критеріями (1989р.) з доповненнями Я. С. Циммермана (1995 р.) та уточненнями MKX-10, а також на основі бальної системи MANNHEIM. Атеросклеротичні зміни діагностували за допомогою УЗД, вимірюючи товщину шару «інтима-медіа» (TIM) загальної сонної артерії у 
Огляди літератури, оригінальні дослідження, погляд на проблему

В-режимі. Потовщення стінки судини на рівні загальної сонної артерії та ії біфуркації до 1,3 мм та більше розцінювали як ультразвукову ознаку атеросклеротичної бляшки. Також в усіх хворих визначали показники ліпідограми та вираховували коефіцієнт атерогенності (КА).

Для виявлення зовнішньосекреторної недостатності підшлункової залози (ЗСН ПЗ) всім хво-

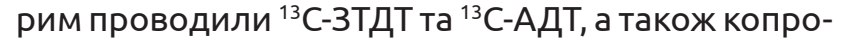
граму.

Ми дослідили та проаналізували вплив таких модифікуючих факторів ризику, як дисліпідемія, ожиріння, куріння, постійні стреси (стан тривоги/ депресії), зловживання алкоголем.

Для виявлення ожиріння всім хворим визначали індекс маси тіла (IMT), вимірювали окружність талії (ОТ). ІМТ розраховували за формулою: IMT = Maca (кг) / Зріст $\left(\mathrm{M}^{2}\right)$. Нормальні значення IMT - 18,5-25, надмірна маса (преожиріння) - 2530, ожиріння - 30 і більше. ОТ в нормі складає: у чоловіків - менше 94 см, у жінок - менше 80 см. ОТ 94-101,9 см у чоловіків та 80-87,9 см у жінок визначається як надмірна вага. ОТ більше 102 см у чоловіків і більше ніж 88 см у жінок свідчить про наявність ожиріння.

Наявність такого фактора ризику як куріння встановлювали шляхом детального збору анамнезу життя пацієнтів.

Порушення ліпідного профілю виявляли шляхом аналізу показників ліпідного обміну (загальний холестерин (3ХC), ліпопротеїди високої щільності (ЛПВЩ), ліпопротеїди низької щільності (ЛПНЩ), ліпопротеїди дуже низької щільності (ЛПДНЩ), індекс атерогенності). Показники ліпідограми визначали на автоматичному біохімічному аналізатоpi ChemWell, Awareness Technology INC (СШA). KA вираховували за формулою: KA=(загальний ХСлПВЩ)/ЛПВЩ.

Для виявлення субклінічних чи клінічних проявів тривоги/депресії всім пацієнтам було проведено анкетування за госпітальною шкалою тривоги та депресії (Hospital Anxiety And Depression Scale-HADS).
Зловживання алкоголем, що $\epsilon$ фактором ризику, встановлювали на основі скарг, зібраного анамнезу (вживання етанолу понад 80 мл на добу протягом 10 і більше років) та методом анкетування за допомогою тесту AUDIT (Alcohol Use Disorders Identification Test).

Методика проведення всіх досліджень відповідала Гельсінській декларації 1975 р. та ії перегляду 1983 р. Статистичну обробку результатів обстеження хворих здійснювали за допомогою комп'ютерної програми STATISTICA 6.1 (фірми StatSoft Inc, USA).

Наукове дослідження $\epsilon$ фрагментом ДБ теми № 851 «Механізми формування ускладнень при захворюваннях печінки та підшлункової залози, методи їх лікування та профілактики" (номер державної реєстрації: 01154001103).

Результати й обговорення. За результатами проведених нами амілазного та тригліцеридного дихальних тестів усіх хворих було поділено на 2 групи залежно від наявності чи відсутності зовнішньосекреторної недостатності підшлункової залози (ЗСН ПЗ). У I групу ввійшли 25 хворих на ХП з вираженою ЗСН ПЗ (більш суттєві порушення ЗСН ПЗ, зокрема зниження сумарної концентрації ${ }^{13} \mathrm{CO}_{2}$ в кінці дослідження (360 хв) до $(18,2 \pm 0,5) \%$ та максимальної концентрації ${ }^{13} \mathrm{CO}_{2}$ між 150 та 210 хв дослідження до $(6,9 \pm 0,85) \%$ за результатами ${ }^{13} \mathrm{C}$-ЗТДТ та зниження сумарної концентрації ${ }^{13} \mathrm{CO}_{2}$ в кінці дослідження $(360$ хв.) до рівня $(8,7 \pm 0,9) \%$ за результатами ${ }^{13} \mathrm{C}-\mathrm{AДТ)}$. II групу склали 19 хворих на ХП без виражених проявів ЗСН ПЗ (зниження сумарної концентрації ${ }^{13} \mathrm{CO}_{2}$ в кінці дослідження (360 хв) до $(24,3 \pm 0,6) \%$ та максимальної концентрації ${ }^{13} \mathrm{CO}_{2}$ між 150 та 210 хв до $(7,3 \pm 0,7) \%$ за результатами

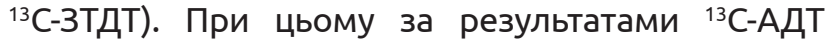
$((11,5 \pm 0,8)$ \%) відхилень від нормальних показників не встановлено (табл. 1).

Основною скаргою у обстежених хворих на ХП був тупий ниючий біль з локалізацією у верхніх відділах живота, який мав оперізувальний характер та іррадіював у спину, ліве плече, під ліву лопатку (100,0 \%). Також у більшості хворих від-

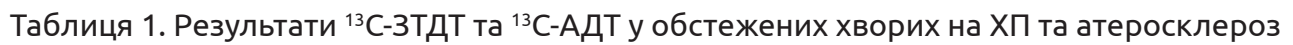

\begin{tabular}{|c|c|c|c|}
\hline Показник & $\begin{array}{c}\text { Контрольна група } \\
(n=20)\end{array}$ & $\begin{array}{c}\text { I група } \\
(n=25)\end{array}$ & $\begin{array}{c}\text { II група } \\
(n=19)\end{array}$ \\
\hline \multicolumn{4}{|c|}{${ }^{13} \mathrm{C}-$ змішаний тригліцеридний дихальний тест } \\
\hline $\begin{array}{l}\text { Максимальна концентрація }{ }^{13} \mathrm{CO}_{2} \\
\text { між } 150 \text { та } 210 \text { хв дослідження, \% }\end{array}$ & $13,6 \pm 1,7$ & $6,9 \pm 0,85$ & $7,3 \pm 0,7$ \\
\hline $\begin{array}{l}\text { Сумарна концентрація }{ }^{13} \mathrm{CO}_{2} \\
\text { в кінці дослідження (360 хв), \% }\end{array}$ & $32,5 \pm 1,2$ & $18,2 \pm 0,5$ & $24,3 \pm 0,6$ \\
\hline \multicolumn{4}{|c|}{${ }^{13} \mathrm{C}$-амілазний дихальний тест } \\
\hline $\begin{array}{l}\text { Сумарна концентрація }{ }^{13} \mathrm{CO}_{2} \\
\text { в кінці дослідження (360 хв), \% }\end{array}$ & $20,3 \pm 2,2$ & $8,7 \pm 0,9$ & $11,5 \pm 0,8$ \\
\hline
\end{tabular}


Огляди літератури, оригінальні дослідження, погляд на проблему мічали диспепсичний синдром у вигляді зниження апетиту (80,1\%), нудоти $(64,5 \%)$, блювання (41,3 \%). Проявом кишкової диспепсії були «пан-

креатичні» проноси з неприємним запахом, стеаторея, здуття живота. У таблиці 2 наведено клінічну характеристику хворих за групами.

Таблиця 2. Зміни клінічної симптоматики у обстежених хворих на ХП та атеросклероз

\begin{tabular}{|c|c|c|}
\hline \multirow{2}{*}{ Клінічні прояви } & \multicolumn{2}{|c|}{ Обстежені хворі на ХП } \\
\hline & I група (n=25) & II група (n=19) \\
\hline Больовий синдром, \% & 100 & 100 \\
\hline \multicolumn{3}{|l|}{ Диспепсичний синдром, \% } \\
\hline - порушення апетиту, \% & 89,3 & 71,6 \\
\hline - нудота, \% & 67,0 & 60,5 \\
\hline - блювання, \% & 51,4 & 35,7 \\
\hline \multicolumn{3}{|l|}{ Синдром кишкової диспепсії } \\
\hline - проноси з неприємним запахом, \% & 100,0 & 3,7 \\
\hline - стеаторея, \% & 66,6 & 2,1 \\
\hline - метеоризм, \% & 50,2 & 26,3 \\
\hline
\end{tabular}

Усім обстеженим була проведена антропомет-

зультати антропометричних вимірювань у хворих рія (визначення ІМТ та ОТ). В таблиці 3 наведено ре-

на ХП та атеросклероз, а також контрольної групи.

Таблиця 3. Результати антропометричного дослідження у хворих на ХП і атеросклероз та контрольної групи

\begin{tabular}{|l|c|c|c|c|c|c|c|c|}
\hline \multirow{2}{*}{ Група } & \multicolumn{9}{|c|}{ Показиики } \\
\cline { 2 - 9 } & \multicolumn{3}{|c|}{ IMT, \% } & \multicolumn{3}{c|}{ ОТ, \% } \\
\cline { 2 - 9 } & норма & $\begin{array}{c}\text { надмірна } \\
\text { маса }\end{array}$ & ожиріння & $\begin{array}{c}\text { недостатня } \\
\text { маса }\end{array}$ & норма & $\begin{array}{c}\text { надмірна } \\
\text { маса }\end{array}$ & ожиріння & $\begin{array}{c}\text { недостатня } \\
\text { маса }\end{array}$ \\
\hline $\begin{array}{l}\text { I група } \\
(n=25)\end{array}$ & 52,0 & 24,0 & 16,0 & 8,0 & 60,0 & 24,0 & 8,0 & 8,0 \\
\hline $\begin{array}{l}\text { II група } \\
(n=19)\end{array}$ & 26,3 & 31,6 & 36,8 & 5,3 & 42,1 & 31,6 & 15,8 & 10,5 \\
\hline $\begin{array}{l}\text { Контрольна група } \\
(n=20)\end{array}$ & 75,0 & 15,0 & 5,0 & 5,0 & 80,0 & 10,0 & 5,0 & 5,0 \\
\hline
\end{tabular}

Відомо, що одним із проявів ЗСН ПЗ є синдроми мальдигестії та мальабсорбції, які неминуче супроводжуються втратою ваги у даних хворих. Слід зазначити, що при аналізі результатів антропометрії у обстежених нами пацієнтів виявлено протилежні результати, а саме: недостатню масу тіла у хворих із ЗСН ПЗ як І, так і ІІ груп діагностовано лише у 8 \% та 5,3 \% відповідно. Надмірну масу тіла чи ожиріння також було виявлено частіше у хворих без вираженої ЗСН П3 (68,4 \%), порівняно із групою пацієнтів із ЗСН ПЗ (40,0%). У контрольної групи надмірна маса тіла чи ожиріння відмічається у близько 20,0 \% обстежуваних. Це, ймовірно, можна пояснити поєднаними впливами на масу тіла двох суміжних патологічних процесів в організмі, таких як ЗСН ПЗ при ХП з атеросклерозом, який у даних пацієнтів перебігає паралельно.

Для виявлення дисліпідемії всім хворим було проведено аналіз ліпідограми та вираховано КА. У таблиці 4 наведено показники ліпідного обміну у хворих на ХП по групах, а також дані контрольної групи $(p<0,05)$.

Таблиця 4. Зміни показників ліпідного обміну у хворих на ХП та атеросклероз та контрольної групи $(p<0,05)$

\begin{tabular}{|c|c|c|c|}
\hline Показник & $\begin{array}{l}\text { Контрольна група } \\
(n=20)\end{array}$ & Хворі на ХП із ЗСН ПЗ (n=25) & $\begin{array}{c}\text { Хворі на ХП без вираженої } \\
\text { ЗСН ПЗ }(n=19)\end{array}$ \\
\hline ТГ, ммоль/л & $1,2 \pm 0,13$ & $2,3 \pm 0,09 *$ & $3,94 \pm 0,21 * *, \wedge$ \\
\hline ЗХ, ммоль/л & $4,55 \pm 0,24$ & $7,46 \pm 1,3 *$ & $8,77 \pm 0,86 * *$ \\
\hline ЛПнЩ, ммоль/л & $3,3 \pm 0,54$ & $4,1 \pm 0,82$ & $5,9 \pm 0,22^{*}$ \\
\hline лПДНЩ, ммоль/л & $0,14 \pm 0,67$ & $2,4 \pm 0,31 * *$ & $1,86 \pm 0,99 * *$ \\
\hline ЛПВЩ, ммоль/л & $2,7 \pm 0,33$ & $1,12 \pm 0,21^{*}$ & $0,92 \pm 0,32 *$ \\
\hline KA & $1,67 \pm 0,56$ & $4,62 \pm 0,47 * *$ & $5,60 \pm 0,15 * *$ \\
\hline
\end{tabular}

Примітки: 1. Різниця між показниками контрольної групи та хворими I та II груп достовірна: * $(p<0,05)$; ** $(p<0,01)$. 2. Різниця між показниками I та II груп достовірна: ^ $(p<0,05)$. 
Огляди літератури, оригінальні дослідження, погляд на проблему

Аналізуючи наведені вище результати ліпідограми ми виявили порушення у всіх обстежуваних нами пацієнтів. Проте більш виражені порушення відмічали у хворих на ХП без вираженої $3 \mathrm{CH}$ ПЗ, а

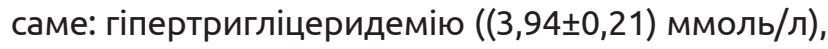
гіперхолестеринемії $((8,77 \pm 0,86)$ ммоль/л), зниження рівня лПвЩ $((0,92 \pm 0,32)$ ммоль/л), підвищення

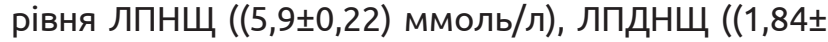
$0,99)$ ммоль/л) та КА $(5,60 \pm 0,15)$. Показники ліпідограми у хворих на ХП із ЗСН ПЗ також перевищували норму, проте їх значення були достовірно меншими. Відомо, що модифікуючі фактори ризику атеросклерозу, які супроводжуються розвитком запальних змін з наступною загибеллю ацинарних клітин та їх заміною на адипоцити, сприяють формуванню жирової дистрофії та прогресуванню ЗСН ПЗ.

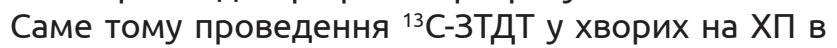
поєднанні з атеросклерозом дає можливість виявити ЗСН ПЗ на ранній стадії та при усуненні факторів ризику (надмірна маса тіла, порушення ліпідного обміну, куріння, постійні стреси) та адекватному лікуванні сприяє зворотному розвитку стеатозу ПЗ.

За результатами проведеного нами опитування така шкідлива звичка як куріння (в тому числі пасивне куріння) спостерігалася у 60,0 \% хворих I групи та у 57,9 \% хворих II групи відповідно, що свідчить про шкідливий вплив куріння на перебіг атеросклерозу, а також ХП. У обстежених контрольної групи цей показник становив 10,0\%.

Усім хворим було проведено анкетування за госпітальною шкалою тривоги та депресії HADS. При аналізі отриманих результатів, як ми і очікували, було виявлено субклінічні чи клінічні прояви тривоги/депресії у 72,0 \% хворих I групи та у 47,4 \% обстежених пацієнтів II групи.

Частота виявлення субклінічних (6-9 балів за шкалою HADS) та клінічних проявів (10 і більше балів за шкалою HADS) тривоги у хворих I групи склала 44,0 \%, у пацієнтів II групи - 31,6 \% відповідно. Цей показник у обстежених контрольної групи склав 15,0\%. Частота виявлення субклінічних (6-9 балів за шкалою HADS) та клінічних проявів (10 і більше балів за шкалою HADS) депресії була на рівні 28,0 \% у пацієнтів з вираженою клінічною картиною ЗСН ПЗ та 15,8 \% у пацієнтів без клінічної симптоматики ЗСН ПЗ. У контрольній групі цей показник склав 5,0 \%.

Аналіз отриманих результатів анкетування показав, що у хворих I групи достовірно частіше спостерігаються субклінічні та клінічні прояви тривоги/депресії, порівняно з пацієнтами II групи та обстеженими контрольнї групи $(p<0,05)$. У таблиці 5 наведено результати проведеного анкетування за шкалою HADS.

Таблиця 5. Результати анкетування за шкалою HADS у хворих на ХП та обстежених контрольної групи

\begin{tabular}{|l|c|c|c|}
\hline \multicolumn{1}{|c|}{ Показник } & $\begin{array}{c}\text { Контрольна група } \\
(n=20)\end{array}$ & $\begin{array}{c}\text { I група } \\
(\mathrm{n}=25)\end{array}$ & $\begin{array}{c}\text { II група } \\
(\mathrm{n}=19)\end{array}$ \\
\hline Субклінічні та клінічні прояви тривоги, \% & 15,0 & $44,0^{\wedge *}$ & $31,6^{*}$ \\
\hline Субклінічні та клінічні прояви депресії, \% & 5,0 & $28,0^{\wedge *}$ & $15,8^{*}$ \\
\hline
\end{tabular}

Для виявлення у обстежуваних пацієнтів зловживання алкоголем всім хворим було проведе- но анкетування за допомогою тесту AUDIT. Peзультати анкетування наведено в таблиці 6 .

Таблиця 6. Результати тестування за шкалою AUDIT у хворих на ХП та обстежених контрольної групи

\begin{tabular}{|c|c|c|c|}
\hline Показник & $\begin{array}{c}\text { Контрольна група } \\
(\mathrm{n}=20)\end{array}$ & $\begin{array}{l}\text { I група } \\
(\mathrm{n}=25)\end{array}$ & $\begin{array}{r}\text { II група } \\
(\mathrm{n}=19)\end{array}$ \\
\hline Безпечне вживання алкоголю (1-7 балів), \% & 80,0 & 20,0 & 26,3 \\
\hline Небезпечне вживання алкоголю (8-15 балів), \% & 10,0 & 16,0 & 21,1 \\
\hline $\begin{array}{l}\text { Шкідливе вживання алкоголю, яке шкодить фізичному та } \\
\text { психічному здоров'ю (16-19 балів), \% }\end{array}$ & 5,0 & 24,0 & 21,1 \\
\hline Синдром алкогольної залежності (більше 20 балів), \% & 5,0 & 40,0 & 31,5 \\
\hline
\end{tabular}

Примітки: 1. * - між показниками обстежених контрольної групи та хворих на ХП виявлена статистично достовірна різниця p<0,05. 2. ^ - статистично достовірна різниця між показниками у хворих I та II груп, $p<0,05$.

Результати анкетування свідчать, що надмірне вживання алкоголю спостерігається у близько 80,0 \% обстежених нами хворих на ХП, незалежно від ступеня ЗСН ПЗ. У обстежених контрольної групи цей показник знаходився на рівні $20,0 \%$. Тобто, залежності у групах хворих з ХП без вираженої клініки ЗСН ПЗ та хворих на ХП з вираженою клінічною картиною $3 \mathrm{CH}$ ПЗ не було виявлено.

Аналіз факторів ризику атеросклерозу у хворих на ХП залежно від наявності чи відсутності $3 \mathrm{CH}$ ПЗ показав, що всі досліджувані нами модифікуючі фактори мають місце у обстежених нами хворих на ХП та атеросклероз. Проведене нами дослідження 
Огляди літератури, оригінальні дослідження, погляд на проблему

показало, що в осіб з атеросклерозом та ураженням ПЗ створюється несприятливий метаболічний фон. Особливо актуальним $\epsilon$ виявлення ЗСН ПЗ ще на ранніх етапах формування (до клінічних проявів). Проведення ${ }^{13}$ С-ЗТДТ у хворих на ХП в поєднанні з атеросклерозом дає можливість виявити дані порушення вже на ранніх етапах розвитку та підтвердити пригнічення функціональної активності панкреатоцитів та етапі жирової дистрофії ПЗ. Виявлення модифікуючих факторів АС у хворих на ХП дає змогу провести їх корекцію, що, в свою чергу, також $\epsilon$ важливим елементом для профілактики прогресування ХП у даних пацієнтів.

\section{ЛІТЕРАТУРА}

1. Бабінець Л. С. Клініко-патогенетичні аспекти хронічного панкреатиту біліарного генезу та ожиріння / Л. С. Бабінець, К. Ю. Кицай // Гастроентерологія. 2016. - № 1 (59). - С. 86-92.

2. Корнацький В. М. Методологія профілактики і ранньої діагностики хвороб системи кровообігу в сучасних умовах / В. М. Корнацький, А. П. Дорогой, Д. М. Мороз // Український кардіологічний журнал. 2015. - № 1. - С. 75-80.

3. Губергриц Н. Б. Неалкогольная жировая болезнь поджелудочной железы / Н. Б. Губергриц, Т. М. Хрис-
Висновки. 1. У хворих на ХП та АС встановлено негативний вплив таких модифікуючих факторів ризику, як дисліпідемія, куріння, надлишкова маса тіла, постійні стреси, надмірне вживання алкоголю на прогресування поєднаної патології. 2. У хворих на ХП та АС виявлено особливості вгодованості, а саме: при поєднанні цих патологічних станів більш характерні надмірна вага чи ожиріння, ніж недостатня вгодованість.

Перспективи подальших досліджень полягають у подальшому вивченні впливу модифікуючих факторів ризику атеросклерозу у хворих на $\mathrm{XП} \mathrm{та} \mathrm{AC.}$

\title{
REFERENCES
}

1. Babinets, L.S., Kutsai, K.Yu. (2016). Kliniko-patohenetychni aspekty khronichnoho pankreatytu biliarnoho henezu ta ozhyrinnia [Clinical and pathogenetic aspects of chronic pancreatitis of biliary origin and obesity]. Hastroenterolohiia - Gastroenterology, 1 (59), 86-92 [in Ukrainian].

2. Kornatskyi, V.M., Dorohoi, A.P., \& Moroz, D.M. (2015). Metodolohiia profilaktyky i rannoi diahnostyky khvorob systemy krovoobihu v suchasnykh umovakh [Methodology of prevention and early diagnosis of circulatory system diseases in modern conditions]. Ukrainskyi kardiolohichnyi zhurnal - Ukrainian Cardiology Journal, 1, 75-80 [in Ukrainian].

3. Gubergrits, N.B., Khristich, T.M., \& Bondarenko, O.A. (2013). Nealkoholnaya zhyrovaya bolezn podzheludochnoy

тич, О. А. Бондаренко. - Донецк : Лебедь, 2013. $234 \mathrm{c}$.

4. Гаркуша С. Л. Досвід роботи кабінету корекції ліпідного спектра крові та лікування різних форм ожиріння у профілактиці виникнення захворювань системи кровообігу / С. Л. Гаркуша, В. Н. Корзун // Довкілля та здоров' я. - 2015. - № 1 (72). - С. 31-34.

5. Van Raalte D. H. Pancreatic steatosis in humans: cause or marker of lipotoxicity? / D. H. van Raalte, N. J. van der Zijl, M. Diamant // Curr. Opin. Clin. Nutr. Metab. Care. 2010. - Vol. 13. - P. 478-485.

zhelezy [Non-alcoholic fatty pancreatic disease]. Donetsk: Lebed [in Russian].

4. Harkusha, S.L., \& Korzun, V.N. (2015). Dosvid roboty kabinetu korektsii lipidnoho spektra krovi ta likuvannia riznykh form ozhyrinnia u profilaktytsi vynyknennia zakhvoriuvan systemy krovoobihu [The experience of the office of correction of the lipid spectrum of blood and treatment of various forms of obesity in the prevention of diseases of the blood circulation system]. Dovkillia ta zdoroviaEnvironment and Health, 1 (72), 31-34 [in Ukrainan].

5. Van Raalte, D.H., van der Zijl, N.J., Diamant, M. (2010). Pancreatic steatosis in humans: cause or marker of lipotoxicity? Curr. Opin. Clin. Nutr. Metab. Care., 13, 478485.

\section{СТРАТИФИКАЦИЯ МОДИФИЦИРУЮЩИХ ФАКТОРОВ РИСКА АТЕРОСКЛЕРОЗА У БОЛЬНЫХ ХРОНИЧЕСКИМ ПАНКРЕАТИТОМ}

ОЕ. С. Сирчак, С. М. Опаленик

\author{
ГВУЗ «Ужгородский национальный университет»
}

РЕЗЮМЕ. В статье описано и проанализировано влияние основных модифицирующих факторов риска атеросклероза у больных хроническим панкреатитом.

Цель исследования-выявить и исследовать наличие факторов риска атеросклероза у больныххроническим панкреатитом в сочетании с нарушением липидограммы.

Материал и методы. Всем больным были проведены ${ }^{13} \mathrm{C}-$ смешанный триглицеридный дыхательный тест

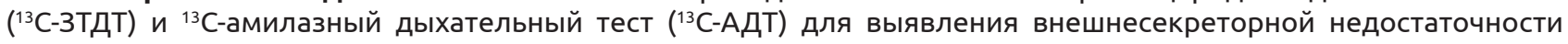


Огляди літератури, оригінальні дослідження, погляд на проблему

поджелудочной железы. Атеросклеротические изменения диагностировали измеряя толщину слоя «интимамедиа» в сонной артерии и при наличии нарушений в липидограмме (определением содержания общего холестерина плазмы крови (ОХ), триглицеридов (ТГ), холестерина липопротеидов высокой плотности (ЛПВП) и липопротеидов низкой плотности (ЛПнП), коэффициента атерогенности (КА)).

Результаты. У всех больных было выявлено недостаточность поджелудочной железы по результатам ${ }^{13} \mathrm{C}-3 Т Д Т$

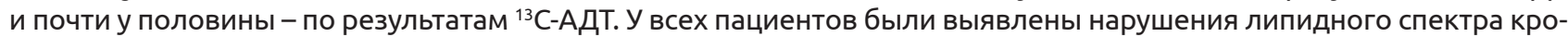
ви в виде гиперхолестеринемии, гипертриглицеридемии, повышения КА. Доказано, что ожирение или недостаточная масса тела не может служить критерием определения степени недостаточности поджелудочной железы или тяжести атеросклеротических нарушений у больных ХП в сочетании с атеросклерозом. Установлено, что ${ }^{13}$ С-ЗТДТ является методом выбора для ранней диагностики недостаточности поджелудочной железы. С помощью методов тестирования, анкетирования и опроса выявлено существенное влияние модифицирующих факторов риска атеросклероза на течение ХП.

КЛючЕВЫЕ СЛОВА: атеросклероз; хронический панкреатит; модифицирующие факторы риска.

\title{
STRATIFICATION OF MODIFIED RISK FACTORS OF ATHEROSCLEROSIS IN PATIENTS WITH CHRONIC PANCREATITIS
}

\section{Uzhhorod National University}

\author{
@E. S. Sirchak, S. M. Opalenik
}

SUMMARY. The article describes and analyzes the influence of the main risk factors of atherosclerosis in patients with chronic pancreatitis.

The aim of the study - to identify and research risk factors of atherosclerosis in patients with combination of chronic pancreatitis and dyslipidemia.

Material and Methods. We conducted mixed triglyceride 13C breath test (13C-MTBT) and amylase 13C-breath test (13C-ABT) for detection of exocrine pancreatic insufficiency (EPI). Atherosclerotic changes were diagnosed by measuring the thickness of the intima-media layer in the carotid artery and changes in the lipid profile of the blood (by determining the total blood plasma cholesterol (CF), triglycerides (TG), high density lipoprotein cholesterol (HDL), low density lipoprotein (LDL) and atherogenicity).

Results. The exocrine pancreatic insufficiency was observed in all patients by using the triglyceride respiratory test. The violation of the lipid profile, namely: hypercholesterolemia, hypertriglyceridemia, and increase in atherogenicity was found in all patients. It has been shown that obesity or insufficient body weight cannot serve as a criterion for determining the degree of exocrine pancreatic insufficiency or the severity of atherosclerotic disorders in patients with combination of chronic pancreatitis and atherosclerosis. It is proved that triglyceride respiratory test is a method of choice for early diagnosis of exocrine pancreatic insufficiency. The significant influence of the modified risk factors of atherosclerosis on the course of chronic pancreatitis was revealed by using the testing methods, questionnaires and surveys.

KEY WORDS: atherosclerosis; chronic pancreatitis; modified risk factors. 